\title{
Reef Conservation off the Hook: Can Market Interventions Make Coral Reef Fisheries More Sustainable?
}

\author{
Katie L. Cramer ${ }^{1,2,3 *}$ and John N. Kittinger ${ }^{2,3,4}$ \\ ${ }^{1}$ Center for Biodiversity Outcomes, Global Institute of Sustainability and Innovation, Arizona State University, Tempe, AZ, \\ United States, ${ }^{2}$ Conservation International, Center for Oceans, Honolulu, HI, United States, ${ }^{3}$ Conservation International, \\ Betty and Gordon Moore Center for Science, Arlington, VA, United States, ${ }^{4}$ Global Futures Laboratory, School of \\ Sustainability, Arizona State University, Tempe, AZ, United States
}

The overexploitation of coral reef fisheries threatens the persistence of reef ecosystems and the livelihoods and food security of millions of people. Market-based initiatives to increase fisheries sustainability have been widely implemented in industrialized commodity fisheries, but the suitability of these initiatives for coral reef fisheries has not been systematically investigated. Here, we present a typology of market-based interventions and coral reef fisheries sectors and identity promising approaches for each fishery archetype. For high value, export-oriented reef fisheries that are highly unsustainable (live reef food fish and dried sea cucumbers), traditional regulatory efforts including trade restrictions will be most effective. For high-value, export-oriented fisheries for highly fecund invertebrates (lobsters and mollusks), certification and ratings efforts, fishery improvement projects, and sustainable purchasing commitments can improve fishing practices and increase fisher market access and revenue. For lowervalue fisheries targeting species for domestic or regional consumption, sustainable purchasing commitments among local buyers, consumer awareness campaigns, and local certification and ratings schemes hold promise for shifting attitudes toward sustainability and increasing food security for local communities. Finally, fisher empowerment efforts including direct access to local markets and market information, training on improved post-harvest methods, and formation of fisher associations hold promise for increasing fisher incomes, reducing wasteful catch, increasing food security, and de-incentivizing unsustainable practices. Despite the potential of market-based interventions, specific approaches must be carefully tailored to the ecological and social reality of these systems, including the inherent unsustainability of commercial coral reef fisheries, the limited capacity for fisheries governance, the limited financial support of market-based initiatives, and the threatened status of coral reef ecosystems globally.

Keywords: coral reefs, markets, sustainability, fisheries, conservation, seafood

\section{INTRODUCTION}

Coral reefs are in crisis due to overfishing, pollution, and climate change (Hughes et al., 2003; Pandolfi et al., 2003; Burke et al., 2011), threatening the persistence of reef ecosystems and the wellbeing of tens of millions of people that depend on reefs for food and livelihood security (Moberg and Folke, 1999; Teh et al., 2013; Birkeland, 2017). Coral reef fisheries contribute up to one-quarter 
of the total fish catch in developing countries (Jameson et al., 1995) and account for more than one-quarter of all smallscale fishers (Teh et al., 2013). Reef fisheries are intensely exploited as a local source of protein and for export-oriented trades including the aquarium, live reef food fish, and dried sea cucumber ("beche-de-mer") trades (Sadovy et al., 2003; Wabnitz et al., 2003; Purcell et al., 2013). But because coral reef environments are characterized by low export production, tightly integrated ecosystem components, and species with irregular and slow recruitment, coral reef fisheries are easily overexploited (Birkeland, 2017). As a result, over 75\% of coral reef fisheries are currently being fished at unsustainable levels (MacNeil et al., 2015) and fishing has been identified as a major threat to coral reef ecosystem resilience (Newton et al., 2007). The sustainability of coral reef fisheries is further threatened by projected increased demand, coastal development and ocean pollution, invasive species, and the mass die off of reef-building corals from climate change (Dalzell et al., 1996; Pratchett et al., 2008; Green et al., 2012). It is therefore essential to reduce the magnitude of disturbance to coral reefs caused by fishing and other human activities to ensure their continued ecological functioning and provisioning of essential benefits to humanity.

To mitigate the unsustainable production practices in wildcapture fisheries and seafood farming (aquaculture), significant investments have been made in market-based solutions. Marketbased solutions include a variety of approaches focused on generating incentives along the seafood supply chain (i.e., producers, buyers, distributors, retailers) that favor sustainability (Sutton, 1998; Jacquet et al., 2009; Kittinger et al., 2021). The general theory of change for market-based approaches posits that shifting demand toward sustainability will motivate and enable seafood producers and supply chains to improve practices and the overall sustainability of fisheries (Ross Strategic et al., 2020), drawing from a wider body of theory and practice encompassed in market transformations (Simons, 2017). These schemes are predominantly applied in large-scale, industrialized fisheries that supply markets in developed countries where consumer demand for sustainable seafood is greater, governance and government support are strong, and the significant investment required to participate in sustainability programs is financially viable.

In contrast, coral reef fisheries are typically small-scale and located in (and often supply markets in) developing countries with lower capacity for fisheries management and governance. These fisheries have largely been excluded from voluntary (i.e., non-regulatory) market-based approaches (Wakamatsu and Wakamatsu, 2017). However, existing research has shown that market gravity (a function of human population density and market access) is a strong predictor of overall reef condition (Brewer et al., 2013; Cinner et al., 2018), suggesting that markets have a pervasive influence on reefs, and that market-based interventions could be catalytic in improving the sustainability of coral reef fisheries. However, the suitability of existing marketbased approaches has not yet been systematically investigated for coral reef fisheries. This remains a major research gap that prevents the development of solutions to address the coral reef crisis.
In this study, we assess the potential for market-based approaches to improve the sustainability of coral reef fisheries. First, we present an assessment of coral reef fisheries sectors, derived analytically from global catch data. We then present a typology of market-based interventions that may be particularly suitable for these sectors. Based on a thorough review of existing initiatives from coral reef and other fisheries, we then map promising interventions to each of our fisheries archetypes. We conclude by discussing the sustainability benefits and limitations associated with each of these interventions and offer modifications that may enable existing interventions to be successfully applied to coral reef fisheries.

\section{Market-Based Solutions for Ocean Resources}

As noted above, market-based interventions comprise a wide array of approaches focused on generating incentives along the supply chain that favor sustainability. In broad terms, market-based approaches can be grouped into three different categories: (1) governmental regulation (of markets and market actors); (2) voluntary private sector commitments; and (3) capacity building initiatives (Table 1). Regulatory approaches include a diverse set of policy levers that governments employ to influence markets and the various business actors engaged in the fisheries sector. In these approaches, sustainability is delineated via governmental legal instruments and policies that mandate fishers and businesses comply with requirements. These requirements may take three general forms: trade policies that restrict the flow of fisheries products across national boundaries, input controls that determine who can fish, when they can fish and how they may fish, and output controls that dictate the amount and type of catch - thus restricting the quantity, quality, composition, and timing of the flow of seafood products into market systems. Whereas harvesters and aquaculture farms have long been subject to policies that dictate operation and management of these production systems (e.g., licensing and permitting, gear/temporal/geographic restrictions, and import/export regulations) and supply chain actors are familiar with requirements on seafood handling (i.e., for food safety), governmental policies for regulating markets toward sustainability are relatively new. However, regulatory efforts to prevent overharvesting on coral reefs are increasing: Kiribati, the Philippines, Indonesia, Palau, and Tonga have restricted the commercial sale and/or export of numerous coral reef species, several Caribbean nations (Barbuda, Bermuda, Belize, Bonaire, Curacao, Turks and Caicos, Dominican Republic, Mexico, and Saint Vincent and the Grenadines) have banned or significantly restricted the fishing of ecologically important herbivorous reef fishes, and the harvesting of ornamental reef species has been restricted in Hawai'i and several Pacific Island nations (Dee et al., 2014; Jackson et al., 2014; Birkeland, 2017; Republic of Palau, 2019). Governments can also provide incentives such as vessel buybacks in efforts to reduce fishing effort, although fisheries subsidies often distort markets and drive unsustainable practices (Clark et al., 2005; Schuhbauer and Sumaila, 2016). 
TABLE 1 | Coral reef fishery archetypes.

\begin{tabular}{|c|c|c|c|c|c|}
\hline $\begin{array}{l}\text { Fisheries } \\
\text { Archetype }\end{array}$ & Scale and Gear & Spatial Extent & Market Access & $\begin{array}{l}\text { Dominant Species by } \\
\text { Catch }\end{array}$ & Examples \\
\hline Industrial & $\begin{array}{l}\text { Large-scale and } \\
\text { commercial: using large } \\
\text { motorized vessels requiring } \\
\text { large sums to maintain and } \\
\text { higher technology gear } \\
\text { such as acoustic sounders, } \\
\text { GPS, aircraft }\end{array}$ & $\begin{array}{l}\text { Domestically, within } \\
\text { neighboring countries' } \\
\text { EEZs, and/or on high seas }\end{array}$ & International, regional & $\begin{array}{l}\text { Threadfin breams, } \\
\text { jacks/pompanos, } \\
\text { drums/croakers, } \\
\text { lizardfishes, mollusks }\end{array}$ & $\begin{array}{l}\text { Lobster, offshore grouper } \\
\text { and snapper }\end{array}$ \\
\hline Artisanal & $\begin{array}{l}\text { Small-scale and } \\
\text { commercial: using smaller } \\
\text { vessels and low-technology } \\
\text { gear such as hand lines, } \\
\text { gillnets, weirs, traps, } \\
\text { cyanide }\end{array}$ & $\begin{array}{l}\text { Domestically, limited to } \\
\text { "inshore fishing area" } \\
\text { (coastal area to a maximum } \\
\text { of } 50 \mathrm{~km} \text { from coast or to } \\
200 \mathrm{~m} \text { water depth) }\end{array}$ & International, regional, local & $\begin{array}{l}\text { Jacks/pompanos, } \\
\text { mollusks, drums/croakers, } \\
\text { lizardfishes, threadfin } \\
\text { breams }\end{array}$ & $\begin{array}{l}\text { Lobster, live reef food fish, } \\
\text { chilled/frozen fish, } \\
\text { aquarium trade, } \\
\text { beche-de-mer, octopus }\end{array}$ \\
\hline Subsistence & $\begin{array}{l}\text { Small-scale and } \\
\text { non-commercial: for } \\
\text { consumption by one's } \\
\text { family or local community } \\
\text { by non-commercial fishers; } \\
\text { also includes catch of } \\
\text { artisanal boats that is given } \\
\text { away to the crews' families } \\
\text { or the local community }\end{array}$ & Inshore fishing area & $\begin{array}{l}\text { None (household or village } \\
\text { consumption) }\end{array}$ & $\begin{array}{l}\text { Jacks/pompanos, } \\
\text { lizardfishes, } \\
\text { drums/croakers, threadfin } \\
\text { breams, porgies and } \\
\text { seabreams }\end{array}$ & $\begin{array}{l}\text { Variety of lower-value fish } \\
\text { and invertebrate species }\end{array}$ \\
\hline
\end{tabular}

Archetypes, scale and gear, and spatial extent adapted from fisheries categorizations developed by Sea Around Us Project (www.seaaroundus.org/catch-reconstructionand-allocation-methods/; Pauly and Zeller, 2015).

Voluntary private sector commitments include an array of corporate social responsibility policies which private sector actors develop and institute into business practices (CEA, 2014; Kittinger et al., 2021). For voluntary approaches, sustainability is driven by voluntary commitments from buyers (e.g., grocery chains, hotels, and restaurants), processors, or sellers, with the intent of generating demand signals for sustainable seafood in the supply chain. Key examples include sourcing commitments and associated policy requirements, and requirements for traceability and transparency systems to ensure sustainability throughout the supply chain (Table 1). Among the most important elements of these approaches are the seafood certification and ratings systems, which have significant recognition among market actors (Certification and Ratings Collaboration, 2020). Certification and ratings systems are supported by their associated standards and verification systems and communicated to consumers and buyers via ecolabels and branding. Verification is often supported by catch documentation and traceability programs that include records of production and product movement throughout the chain of custody, with associated auditing and oversight platforms. Certification is often achieved via fishery improvement projects (collaborative initiatives that include stakeholders throughout a fishery's supply chain and often involve support from government and environmental nongovernmental organizations) that help to address sustainability and fishery data shortcomings (Conservation Alliance for Seafood Solutions, 2021). Certification and ratings systems have widespread adoption among businesses, particularly in developed countries (CEA, 2014; Roheim et al., 2018). Seafood ratings guides are also utilized by retailers including grocery and restaurant chains to meet their seafood sustainability commitments (Seafood Watch, 2020). Consumer education campaigns and programs are also often employed to elevate demand for sustainability in the marketplace and include regional sustainable seafood guides (initially geared toward consumers in North America, Europe, and Australia but expanding to consumers in Asia and several developing reefadjacent nations) and supermarket sustainability rankings (Certification and Ratings Collaboration, 2020).

Voluntary private sector commitments were originally designed for commodity seafood (i.e., seafood from singlespecies industrialized fisheries or industrialized aquaculture sectors) and have been adopted primarily by large-scale seafood buyers in developed countries. In more developed nations, these schemes have resulted in greater interest in sustainability being transmitted throughout the supply chain, from food manufacturers, retailers, restaurants, and consumers (Gutierrez et al., 2016; Ross Strategic et al., 2020). However, it is uncertain to what degree these approaches have translated into meaningful progress toward sustainability within the global fisheries sector: the majority of seafood remains uncertified, most participating fisheries have been certified for less than five years, and independent verification of sustainability improvements for fisheries that have been certified or are in the process of certification are scarce (Blackmore et al., 2015; Certification and Ratings Collaboration, 2020). Although it has been difficult to quantify the ecological gains resulting from market-based approaches in general (Ross Strategic et al., 2020), there is evidence that certification, ratings, and improvement programs have resulted in tangible sustainability benefits (Blackmore et al., 2015; Carlson and Palmer, 2016; Cannon et al., 2018). 
Another key category of market-based interventions includes a broad set of capacity building efforts focused on empowering reef stakeholders. These efforts aim to increase sustainability by improving fisher livelihoods, as insufficient fisher income can be a catalyst for engaging in unsustainable fishing practices (Purcell et al., 2016; Conservation International, 2019). This category includes three types of activities that empower fishers to more directly engage in markets to enable higher incomes from fishing and disincentivize unsustainable fishing practices: (1) providing fishers with real-time information on the market value of their catch, (2) training communities in improved postharvesting seafood processing methods, and (3) forming fishers associations/cooperatives (Table 1; Bell et al., 2018).

\section{Coral Reef Fisheries}

Most coral reef fisheries are small-scale: they typically involve simple harvesting practices and gear, supply small local and/or informal markets or direct subsistence, and operate in remote locations distant from international markets (Teh et al., 2013; Leenhardt et al., 2016). As most coral reefs are located along the coastlines of developing countries with low fisheries management capacity, coral reef fisheries are generally unmanaged or undermanaged, and most are unassessed (i.e., no catch or effort data exist; Pauly and Zeller, 2014; Friedlander, 2015). These fisheries are complex, with the majority targeting multiple species and individual fishers utilizing various gear types and engaging in multiple fisheries sectors.

Following a previous convention developed for fisheries in general (Pauly and Zeller, 2015), we segregate reef fisheries sectors into three general archetypes: industrial, artisanal, and subsistence (Table 1). Although debates exist about the precise delineation of these fisheries archetypes, the classification scheme we utilize here defines industrial reef fisheries as large-scale and commercial, requiring high investment in larger vessels and higher technology gear, and targeting high-value species in high volumes for export. We define artisanal reef fisheries as small-scale and commercial, employing smaller vessels and lower technology gear, and including high- to moderate-value species for export or domestic markets. Most commercial coral reef fisheries are artisanal and supply the live reef food fish, chilled/frozen fish, and aquarium trades (Wabnitz et al., 2003; Sadovy de Mitcheson and Yin, 2015). Artisanal fisheries also supply local and regional restaurants, hotels, grocery stores, and fish markets, with higher value fishes typically consumed by tourists (Bevilacqua et al., 2019). However, most coral reef fisheries are likely non-commercial or subsistence and include lower value fishes whose consumption is restricted to a household or village. The non-commercial nature of subsistence fishing means that catch is largely unreported but may comprise up to $80 \%$ of total coastal fisheries production in some countries (Dalzell et al., 1996; Grafeld et al., 2017). Underreporting of artisanal fisheries catches destined for domestic markets is widespread as well; these fisheries are largely unmonitored by the governments of developing countries whose limited resources are typically focused on industrial export-oriented fisheries (Sale, 2008).
Among the diversity of reef fisheries globally, it is widely recognized that export-oriented fisheries face the greatest sustainability challenges. The aquarium trade supports livelihoods in predominantly rural and low-income communities and provides high value products primarily to consumers in the developed world. It could therefore provide strong economic incentive for communities to conserve coral reef ecosystems. However, damaging fishing techniques, over-harvesting, and high mortality levels of reef organisms from inadequate handling and transport remain significant barriers to sustainability (Wabnitz et al., 2003). The live reef food fish (LRFF) trade is particularly unsustainable: it targets long-lived and large-bodied fishes that are easy to overexploit and can take generations to recover. Further, it is largely unregulated, demand-driven, and geographically broad and therefore untethered from local supply, and it incentivizes overexploitation because the value of a species increases with rarity (Sadovy and Vincent, 2002; Sale, 2008). The LRFF trade has caused the near extirpation of several of the largest reef fishes such as Napoleon wrasse, bumphead parrotfish, and several groupers (Blackmore et al., 2015; Sadovy de Mitcheson and Yin, 2015). The magnitude of trade in chilled and frozen reef fishes is not well known; it is therefore difficult to assess the sustainability status of this fishery. However, because it is targeting many of the same species overexploited by the LRFF trade as well as ecologically important herbivorous fishes, this industry is likely highly unsustainable (Sadovy de Mitcheson and Yin, 2015). The beche-de-mer trade has resulted in the rapid overfishing of sea cucumber populations on reefs globally, resulting in local extirpations in several locations (Purcell et al., 2013). Sea cucumbers are easily overexploited due to the ease with which they are caught, their slow reproductive rates, and susceptibility to Allee effects due to their broadcast spawning of gametes (Uthicke et al., 2004). Supply chains for artisanal and industrial coral reef fisheries are extremely complex and varied, further complicating reform efforts (see Supporting Information).

\section{Are Market-Based Approaches Suitable for Coral Reef Fisheries?}

To quantify the extent to which coral reef fisheries are entering market channels (and therefore may be amenable to marketbased approaches), we compiled catch and landed values of coral reef fish and invertebrate taxa from 1950-2014 available from the Sea Around Us Project (SAUP). SAUP provides catch reconstructions based on landings data by taxon and country reported by the Food and Agriculture Organization of the United Nations (FAO) and supplemented with additional data sources and statistical models to improve data accuracy and completeness (Pauly and Zeller, 2015). From SAUP's online database, we compiled catch and landings values for all taxa that were reported to occur in coral reef environments in at least $25 \%$ of observations and for countries that contain coral reef habitat in their EEZs (per Teh et al., 2013). We compiled data at the finest taxonomic resolution possible, and included statistics at the level of species, genus, or family (Supplementary Table 1). 
Our analysis shows that commercial coral reef fisheries (i.e., industrial and artisanal) catches have increased dramatically since 1950 , and today account for $9 \%$ of all marine catch and $13 \%$ of landed value of marine catch (Figure 1). This result supports qualitative observations that reef fisheries in developing countries have transformed over the past half-century from primarily a subsistence and social activity to a commercial activity (Sadovy de Mitcheson and Yin, 2015), due to improvements in transportation technology and storage and higher market value and increasing tourism (Kronen et al., 2006; Smith and Zeller, 2016). Therefore, in theory, market-based approaches may be suitable for commercial coral reef fisheries that have access to markets where sustainability is a concern and/or where the application of market-based approaches will result in stakeholder buy-in due to tangible social and/or ecological improvements. However, these figures significantly underestimate subsistence catches on coral reefs, which make up the majority of catch in many parts of the world (Dalzell et al., 1996; Sale, 2008). Lastly, these data show that catches on reefs peaked in the 1990 s or 2000s and have steadily declined since (Figure 1), a clear indicator of overfishing and confirmation of the need for improved sustainability in these fisheries.

\section{POTENTIAL MARKET-BASED INTERVENTIONS}

\section{Regulatory Approaches}

Due to a general lack of scientific information and fisheries management infrastructure and the high reliance of local communities on reef species for food security, traditional regulatory approaches are typically more difficult to implement and enforce for coral reef fisheries (Sadovy, 2005; Friedlander, 2015). As a result, a small subset of regulatory approaches that are relatively simple to follow and enforce are most appropriate for coral reefs (Table 2).

Access rights (such as individual transferable quotas, territorial use rights in fisheries-TURFs, and catch shares) and temporal and geographic restrictions (including marine protected areas) have had positive ecological outcomes with non-reef fisheries but may not be appropriate for most coral reef fisheries because they require strong governance, monitoring, and enforcement. For the same reasons and because many fishers view it as cultural and economic right to fish their local reefs (Brewer, 2011; Cinner, 2014; Birkeland, 2017), catch-based restrictions are difficult to implement for many reef fisheries. In contrast, effort restrictions on highly efficient or damaging gear (including cyanide, dynamite, SCUBA, gillnets, and traps) may be more socially acceptable and relatively easier to implement and enforce (McClanahan and Cinner, 2008; Brewer, 2011; Friedlander, 2015). In places with a recent history of customary governance, traditional approaches such as Customary Marine Tenure, co-management or participatory management, and community based individual transferable quotas may hold promise (Aswani and Sabetian, 2010; Friedlander, 2015; Gardner et al., 2017). For intensive export-oriented coral reef fisheries that have inherently unsustainable elements such as the LRFF, aquarium, and beche-de-mer trades, trade policies such as moratoria on commercial sale, export limits or bans, import bans, and tariffs are most appropriate due to the threatened status of fished species and relatively greater management and governance focus placed on these fisheries (Sadovy, 2005; Purcell et al., 2013; Dee et al., 2014; Ram et al., 2014). Import and export restrictions that have been implemented for reef species have resulted in recovery of stocks in some cases, depending on length of moratoria, degree of enforcement, and species (Friedman et al., 2011). Key exporters of live reef food fish and aquarium species in Southeast Asia, Pacific Islands, and Caribbean have recently taken important steps toward reducing take of vulnerable species via bans on commercial fishing and/or export of certain species (Sadovy de Mitcheson and Yin, 2015). For the aquarium trade, import and export restrictions have shown success when combined with moratoriums on the sale of depleted species, no-take reserves, and tiered quota systems and should be implemented more broadly across this sector (Dee et al., 2014, see Supporting Information for more detail).
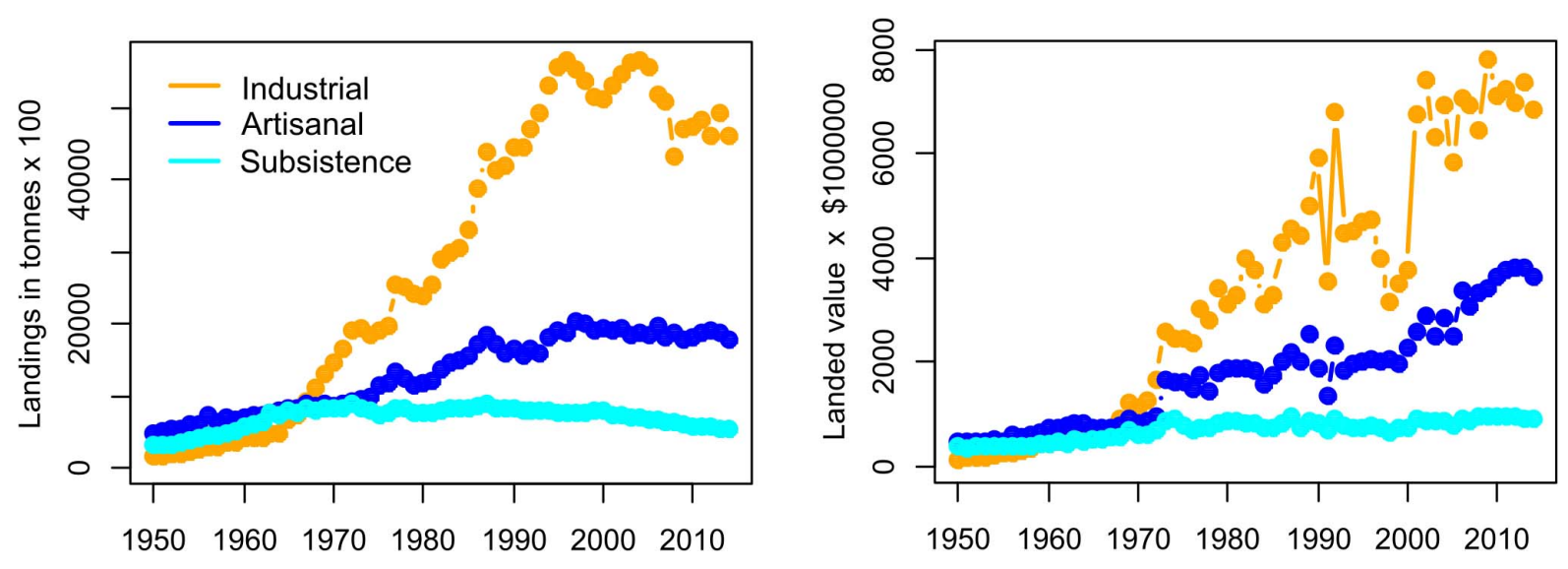

FIGURE 1 | Total catch and landed value of catch for industrial, artisanal, and subsistence coral reef fisheries sectors globally from 1950-2014. Data compiled from Sea Around Us Project. www.seaaroundus.org. 
TABLE 2 | Typology of market-based interventions most applicable to coral reef fisheries.

\begin{tabular}{|c|c|c|c|c|c|c|}
\hline Pathway & Intervention & Mechanism(s) & $\begin{array}{l}\text { Applicable coral reef } \\
\text { fishery archetypes }\end{array}$ & $\begin{array}{l}\text { Applicable fisheries } \\
\text { traits or types }\end{array}$ & Benefits & Challenges/limitations \\
\hline \multirow[t]{2}{*}{ Regulatory } & Trade policies & $\begin{array}{l}\text { Import/export } \\
\text { restrictions or bans, } \\
\text { restrictions on } \\
\text { commercial sale, tariffs }\end{array}$ & $\begin{array}{l}\text { Industrial and artisanal } \\
\text { for export }\end{array}$ & $\begin{array}{l}\text { Overexploited/highly } \\
\text { unsustainable export } \\
\text { fisheries such as LRFF } \\
\text { and beche-de-mer }\end{array}$ & $\begin{array}{l}\text { Does not require strong } \\
\text { fisheries management } \\
\text { system for exporting or } \\
\text { importing country }\end{array}$ & $\begin{array}{l}\text { Lack of governmental } \\
\text { support in regions where } \\
\text { seafood sustainability } \\
\text { movement is nascent }\end{array}$ \\
\hline & $\begin{array}{l}\text { Effort and } \\
\text { catch (input } \\
\text { and output) } \\
\text { controls }\end{array}$ & $\begin{array}{l}\text { Access rights: } \\
\text { licensing, vessel } \\
\text { flagging, permitting, } \\
\text { area-based rights } \\
\text { (Territorial Use Rights } \\
\text { for Fisheries), } \\
\text { catch-based rights } \\
\text { (catch shares/Individual } \\
\text { Transferrable Quotas, } \\
\text { cooperative fishing } \\
\text { rights) }\end{array}$ & $\begin{array}{l}\text { Industrial, artisanal, } \\
\text { subsidence for } \\
\text { domestic and export }\end{array}$ & $\begin{array}{l}\text { Regions with tradition } \\
\text { of customary tenure } \\
\text { and/or fisheries } \\
\text { cooperatives/ } \\
\text { associations; fisheries } \\
\text { engaged in FIPs }\end{array}$ & $\begin{array}{l}\text { Have proven effective for } \\
\text { non-reef fisheries }\end{array}$ & $\begin{array}{l}\text { Requires strong fisheries } \\
\text { governance, monitoring, } \\
\text { and enforcement, which } \\
\text { is lacking for most coral } \\
\text { reef regions }\end{array}$ \\
\hline \multirow[t]{2}{*}{$\begin{array}{l}\text { Voluntary private } \\
\text { sector } \\
\text { commitments }\end{array}$} & $\begin{array}{l}\text { Certification, } \\
\text { rating, } \\
\text { improvement } \\
\text { projects }\end{array}$ & $\begin{array}{l}\text { Certification and ratings } \\
\text { of fisheries, supply } \\
\text { chains, and/or retailers }\end{array}$ & $\begin{array}{l}\text { Industrial and artisanal } \\
\text { for domestic and export }\end{array}$ & $\begin{array}{l}\text { High-value single } \\
\text { species export fishery } \\
\text { targeting highly } \\
\text { fecund/short-lived } \\
\text { species (lobsters, } \\
\text { mollusks) }\end{array}$ & $\begin{array}{l}\text { Increased access to } \\
\text { markets, price premiums, } \\
\text { enhanced } \\
\text { reputation/influence, } \\
\text { increased government } \\
\text { support/stakeholder } \\
\text { participation/fisheries } \\
\text { management, monitoring, } \\
\text { and enforcement }\end{array}$ & $\begin{array}{l}\text { High barriers to entry via } \\
\text { direct and indirect costs, } \\
\text { demand for sustainable } \\
\text { seafood is required, } \\
\text { increased market } \\
\text { access may increase } \\
\text { fishing }\end{array}$ \\
\hline & $\begin{array}{l}\text { Supply chain } \\
\text { engagement }\end{array}$ & $\begin{array}{l}\text { Traceability, } \\
\text { transparency, } \\
\text { accountability efforts }\end{array}$ & $\begin{array}{l}\text { Industrial and artisanal } \\
\text { for domestic and export }\end{array}$ & $\begin{array}{l}\text { IUU fish, aquarium } \\
\text { trade }\end{array}$ & $\begin{array}{l}\text { Reduce IUU fishing, } \\
\text { enable certification of } \\
\text { chain of custody }\end{array}$ & $\begin{array}{l}\text { High costs of } \\
\text { implementation, diffuse } \\
\text { and complex nature of } \\
\text { coral reef fisheries } \\
\text { supply chains }\end{array}$ \\
\hline \multirow[t]{3}{*}{ Capacity building } & $\begin{array}{l}\text { Market } \\
\text { empowerment }\end{array}$ & $\begin{array}{l}\text { Provide fishers with } \\
\text { market information }\end{array}$ & $\begin{array}{l}\text { Industrial and artisanal } \\
\text { for domestic and export }\end{array}$ & $\begin{array}{l}\text { Beche-de-mer, live reef } \\
\text { food fish, lower value } \\
\text { species }\end{array}$ & $\begin{array}{l}\text { Increase fisher income } \\
\text { and livelihood }\end{array}$ & $\begin{array}{l}\text { Requires access to } \\
\text { technology }\end{array}$ \\
\hline & & $\begin{array}{l}\text { Community training on } \\
\text { improved handling and } \\
\text { processing methods }\end{array}$ & $\begin{array}{l}\text { industrial and artisanal } \\
\text { for domestic and export }\end{array}$ & $\begin{array}{l}\text { beche-de-mer, } \\
\text { aquarium trade }\end{array}$ & $\begin{array}{l}\text { increase food security, } \\
\text { reduce waste, increase } \\
\text { market access, increase } \\
\text { income }\end{array}$ & $\begin{array}{l}\text { requires support from } \\
\text { public or private sector }\end{array}$ \\
\hline & & $\begin{array}{l}\text { Formation of fishing } \\
\text { associations/ } \\
\text { cooperatives }\end{array}$ & $\begin{array}{l}\text { Industrial and artisanal } \\
\text { for domestic and export }\end{array}$ & $\begin{array}{l}\text { Beche-de-mer, live reef } \\
\text { food fish, lower value } \\
\text { species }\end{array}$ & $\begin{array}{l}\text { Increase government } \\
\text { support/bargaining } \\
\text { power/fisher income and } \\
\text { livelihood, enable } \\
\text { cooperative governance } \\
\text { based on local ecological } \\
\text { knowledge, enable vertical } \\
\text { integration of supply chain }\end{array}$ & $\begin{array}{l}\text { May not be appropriate } \\
\text { in cultures with strong } \\
\text { tradition of patron-client } \\
\text { arrangements }\end{array}$ \\
\hline
\end{tabular}


Government controls on the volume of aquarium specimens exported have also been effective at increasing price points because rarer fish fetch higher prices (Rhyne et al., 2014). However, because many reef fishers are reliant on fishing for their sole source of income (Cinner, 2014; Purcell et al., 2016), the restriction or banning of one fishing activity may result in shifting to fishing unsustainably or illegally on other reef resources (Conand, 2006; Purcell et al., 2016).

\section{Voluntary Business Commitments Certification Schemes}

Certification schemes are a primary way in which voluntary business commitments are crafted and adhered to. In a sea of certifications, the Marine Stewardship Council (MSC) is the largest wild-capture fisheries program and has the most widely recognized associated ecolabel. Several conditions make it challenging to apply MSC certification to small-scale fisheries in general and coral reef fisheries in particular. First, the theory of change behind MSC certification is that demand for sustainable seafood will incentivize supply of sustainable product, and vice versa (Marine Stewardship Council, 2020), with demand typically driven by voluntary commitments to MSC by large seafood buyers. However, the limited capacity for seafood production from coral reefs prohibits the sustainable harvest of most reef species for international markets (Birkeland, 2017). These ecological constraints mean that suppliers cannot offer sufficient volumes of certified product to generate demand, as consistent and high product volumes are required to maintain brand and image (Sadovy, 2005; Blackmore et al., 2015). Second, coral reef fisheries catches are typically irregular and unpredictable in terms of quantity, quality, and species, restricting their access to export markets and international retailers (Carlson and Palmer, 2016). Third, MSC certification requires a determination that fishing is occurring at sustainable levels, that environmental impacts are minimized, and that fisheries are effectively managed. However, the dearth of scientific information, open access nature, and weak management structures associated with most coral reef fisheries make it difficult to meet these standards (Washington and Ababouch, 2011; Cano Chacon, 2013). Fourth, the majority of seafood produced in developing countries in general and coral reefs in particular is for local consumption, with exported fish often sent to markets where demand for eco-labeled products is relatively low, such as Asia (Tindall, 2009; Carlson and Palmer, 2016). Fifth, MSC certification requires a significant financial investment (to cover fees associated with fisheries pre-assessment/assessment/surveillance audits, certification of chain of custody, and licensing fees for using the MSC logo) that is prohibitively large for most coral reef fisheries. Finally, the diffuse and complex nature of most coral reef fishery supply chains complicates efforts to certify the entire chain of custody.

Despite these challenges, $17 \%$ of fisheries certified by MSC are classified as small-scale (Arton et al., 2020), signifying that this may be a viable pathway for a select group of coral reef fisheries. An analysis of the coral reef fisheries that have been certified by MSC provides insight into the general characteristics of reef fisheries that are amenable to this approach (Supplementary Table 2). All three MSC certified reef fisheries are single-species fisheries for lobster, a highvalue, highly fecund invertebrate primarily destined for export to developed nations, for domestic consumption within a developed nation, or for tourists visiting from developed nations. One of these fisheries, for Western Australia rock lobster, was the first fishery to be certified by Marine Stewardship Council (2009). The other two fisheries, Caribbean spiny lobster in Mexico and the Bahamas, have been certified for a short period, with the former certified for five years before withdrawing from the MSC program due to lack of funds to finance annual audits and the latter certified since 2018. None of these fisheries have realized a price premium from certification-the Western Australia rock lobster fishery primarily reaches the Asian market which traditionally does not place a premium on sustainability, and the Mexican and Bahamian spiny lobster fisheries have not had their chain of custody certified or had MSC logos placed on their products due the additional cost associated with its use (Bellchambers et al., 2016; Pérez-Ramírez et al., 2016). However, certification of Bahamian spiny lobster ensured continued access to the United States market (Travaille et al., 2019) and certification of the Western Australia rock lobster did help the fishery access European markets and reduced European Union tariffs on Australian seafood (Phillips et al., 2003; Marine Stewardship Council, 2009). There have been several nonmonetary benefits to each of these reef fisheries from certification, however, including improved scientific understanding and management of the fisheries, identification of specific actions for improved sustainability, greater coordination and participation of stakeholders in the fisheries management process, and increased governmental support to communities. These benefits have also been reported from small-scale fisheries in developing nations that occur in non-reef habitats (Lopuch, 2008; Cano Chacon, 2013; Bellchambers et al., 2016; Carlson and Palmer, 2016). Certification and pre-certification could help guide local and national fisheries policies, as these processes require adequate monitoring and enforcement efforts (Gulbrandsen, 2009). Despite these non-monetary benefits, the high cost of certification and continued evaluation and meeting of conditions required for re-certification likely precludes lowvalue coral reef fisheries from entering into the MSC system. However, local certification schemes hold promise: programs developed in Colombia, Costa Rica, and Ecuador for reef seafood sold domestically in high-end restaurants have resulted in improved fishery practices and increased fisher revenue (Castrejón and Charles, 2013, 2020; Blue Solutions, 2018; Conservation International, 2019).

Analysis of the coral reef fisheries currently engaged in fishery improvement projects (FIPs) suggests that additional high-value export species may also be amenable to certification or alternative forms of sustainable branding. These include fisheries for high-value species (lobster, octopus, and snapper and grouper) that are primarily for export to North America and European markets (Supplementary Table 2). Except for the snapper and grouper fisheries, fisheries engaged in FIPs 
target 1-2 species with highly selective gear. Reef fisheries have experienced varying levels of progress since the start of FIPs, with several experiencing improved fisheries data collection and monitoring but experiencing little progress with management and enforcement, and a smaller number making improvements with collection, monitoring, and management at a level likely to enable MSC-certification in the near future. Although the initial health of the stock, life history traits of targeted species, degree of sustainability engagement of export markets play a large role in the pace and extent of progress toward sustainability, the biggest predictor of the rate of progress in FIPs appears to be government support and engagement (Supplementary Table 2; CEA, 2020a). For example, the grouper and snapper fisheries face significant obstacles to sustainability because they target hundreds of species and have weak fisheries governance frameworks and management capacity. Nevertheless, each of these fisheries has reported notable progress in scientific data collection, stakeholder participation, development of management structures and processes, and fisher awareness of sustainability issues from engagement in FIPs (Fishery Progress, 2020). Therefore, while export-oriented reef fisheries may be amenable to formal certification, the remainder of reef fisheries will likely not progress beyond FIPs. Given that single-species, high-value coral reef invertebrate fisheries for export appear to be the lower-hanging fruit for successful implementation of certification and ecolabeling schemes, beche-de-mer fisheries could be additional candidates for these efforts (Sampson et al., 2015; Pérez-Ramírez et al., 2016).

Recent developments have increased the potential for additional coral reef seafood to become certified. MSC has created a "Developing World Fisheries Program" with guidelines for the assessment of fisheries in these countries, using local and traditional information, knowledge, and management systems, as well as a risk-based framework to qualitatively assess these data-deficient fisheries (Ponte, 2008). However, the viability of certification schemes for coral reef fisheries will hinge on the degree of community participation. Participation can be increased via engaging in formal community training programs to raise awareness of certification schemes, developing community-based fisheries data collection and training of local independent accessors, and circulation of certification reports to local stakeholders in native and non-technical language (Cano Chacon, 2013; Carlson and Palmer, 2016). Community data collection efforts could be assisted greatly with the use of recently developed technology including smartphone apps (see section "Capacity Building"). To reduce the high barrier to entry for certification schemes, fees can be reduced via support from NGOs or governments and/or creation of a special funding mechanism promoted and managed by certification bodies to which third parties may optionally contribute (Stratoudakis et al., 2016). Lastly, although major coral reef seafood markets in Asia are still in the early stages of engagement in the sustainable seafood movement, the increasing recognition of seafood ecolabels in this region suggests that certification schemes may be meaningfully applied to some reef fisheries in this region (see Supporting Information for examples).

\section{Ratings Systems and Consumer Awareness Campaigns}

While seafood sustainability ratings systems have gained widespread recognition in North America and Europe, they are less prevalent in the primary markets for reef seafood, Asia and Latin America. As a result, most ratings systems and consumer awareness campaigns are not focused on reef species. However, regional seafood ratings guides are gaining wider recognition in Asia and Latin America. Sustainable seafood guides currently exist in China, Taiwan, Japan, and Hong Kong (Certification and Ratings Collaboration, 2020; Lin, 2020). Several of these schemes rate grocery stores and restaurants in addition to seafood, providing an opportunity for expanding the scope of seafood ratings guides to imported and domestic reef species in Asia. As sustainable seafood purchasing increases with knowledge of sustainability issues (Zou, 2017; Lawley et al., 2019), these efforts will have the greatest impact when coupled with consumer awareness campaigns.

\section{Buyer Commitments to Sustainable Sourcing}

For coral reef fisheries serving domestic markets, especially in more urbanized areas with substantial tourism, and for export-oriented fisheries, sustainability commitments from buyers, including retailers, grocery stores, hotels, and restaurants may result in improved fishing practices. These sustainability commitments often involve specific reference to certification and ratings schemes. The hospitality industry is increasingly partnering with environmental NGOs to increase the sustainability and traceability of their seafood supply chains (which may include a small number of coral reef species at reef-adjacent hotels). Several major hotel chains have committed to seafood sourcing policies that require the procurement of seafood from fisheries that are certified, in fishery improvement/aquaculture improvement projects, or that are rated as sustainable by reputable seafood guides (CEA, 2020a). These policies have led to hotels directly supporting local fishery improvement projects and have spurred efforts to trace the chain of custody of non-certified local suppliers, theoretically providing an incentive for local reef fisheries to improve their management practices (CEA, 2020a). However, in locations with overfished reefs such as the Caribbean, seafood served at the high-volume restaurants within international hotel chains are not typically sourced from coral reefs. Sustainability commitments from large hotel chains in this region will therefore likely only include select reef species such as lobsters (Wabnitz, 2019).

Seafood sustainability commitments from large grocery and restaurant chains are common in developed countries but are generally not utilized in Asia or less developed countries. These commitments mirror those implemented by hotel chains: policies to source seafood from fisheries that have been certified, are in the process of certification, or that are rated as sustainable in seafood rankings systems (Alfnes, 2017). Although these initiatives have resulted in significant improvements in seafood purchasing practices in several major North American and European seafood retailers, food distributors and contract caterers, the degree to which these policies affect coral reef fisheries is unclear. However, increasing consumer awareness 
of seafood sustainability in Asia suggests that these initiatives have the potential to disincentivize unsustainable reef fishing for export (Xu et al., 2012; Hori et al., 2020). For coral reef seafood sold to domestic markets in developing countries, retailer sustainability commitments are relatively scarce due to a lack of economic incentives. For example, while the business case for seafood sustainability commitments may only exist for large companies with a high public profile and clientele concerned with sustainability (Bailey et al., 2018), seafood retailers in developing countries are more typically comprised of small, locally owned businesses whose clientele place more importance on price than sustainability concerns (Teh et al., 2013). Another obstacle to sustainable seafood sourcing in Asia has been the inability to locate and secure adequate supply. However, conservation NGOs are developing tools to assist Asian buyers, wholesalers, and retailers in locating sustainably caught seafood (Lee, 2020).

For small-scale reef fisheries, sustainability commitments from small-scale retailers may be the most promising path forward. For example, programs in Colombia and Costa Rica reward fisher organizations adhering to sustainable practices with sourcing commitments from high-end restaurants and tourism operators and enhance the reputation of participating retailers via consumer awareness campaigns (Blue Solutions, 2018; Conservation International, 2019). The hospitality industry has several points of leverage for improving the sustainability of reef fisheries for sale domestically. First, tourism is essential to the economies of most reef-bearing countries, and tourist demand for reef seafood places additional stress on depleted reef resources (Smith and Zeller, 2016; Wabnitz, 2019). Second, reef-bearing countries are increasingly focused on promoting high-end ecotourism, providing an environmentally conscious consumer base whose seafood choices may not be primarily price driven (Wabnitz, 2019). Third, tourists appear to be highly receptive to seafood recommendations from restaurant staff, suggesting retailers could easily direct consumers toward sustainable seafood choices (Biery, 2011). Last, tourism-focused sustainable seafood consumption efforts are aligned with national policies of several countries to shift consumption from reef species to more productive pelagic fish stocks as reef resources are continually degraded (Birkeland, 2017; Republic of Palau, 2019).

\section{Traceability and Transparency Efforts}

Voluntary accountability efforts have great potential for reducing illegal, unreported, and unregulated (IUU) fishing in general. However, these efforts could potentially incur high costs of implementation, especially if electronic data systems are required to track seafood products (Bailey et al., 2016). Therefore, traceability and transparency efforts are most suitable for highvalue, export fisheries such as LRFF, aquarium species, and beche-de-mer (Table 2). However, to offset the costs associated with these efforts, adequate demand for sustainable seafood must exist. While the Asian markets to which LRFF and beche-de-mer are primarily destined do not currently place a premium on sustainability, there is consumer interest in sustainability for the aquarium trade (Dee et al., 2014). Therefore, traceability and transparency efforts could be suitable for this industry (but see Supporting Information). In addition, recently implemented traceability programs that use smartphone apps to collect reef catch data have increased fisher collaboration and involvement in management, which may in turn empower them to exert greater control over the supply chain and deincentivize overexploitation (Jeffers et al., 2019; see section "Capacity building").

\section{Capacity Building Enabling Fishers in the Marketplace}

Because coral reef fisheries supply chains are often diffuse and complex and predominantly operate in remote locations, reef fishers often lack access to accurate market information. Market information is typically passed down to individual fishermen via the chain of exporters, transport middlemen and local buyers and is modified according to the interests of the actors at each level (Ferse et al., 2014; Gardner et al., 2017). As a result, reef fishers without accurate market information fish in response to information given by buyers rather than according to real market demand, leaving them vulnerable to exploitation (Crona and Bodin, 2010; Ram et al., 2014; Purcell et al., 2016). Providing fishers with timely and accurate information on market prices may allow them to adjust to changing market conditions to maximize their income, in theory reducing the economic imperative to overfish (Pauly and Chua, 1988; Purcell et al., 2013). As cellular coverage and cell phone usage spreads globally, smartphone apps are being implemented that increase coral reef fisheries data collection, including gathering and reporting catch data (Frost, 2017; Jeffers et al., 2019), monitoring illegal, unreported, and unregulated fishing (Environmental Justice Foundation, 2014; Nisanala et al., 2015; CEA, 2020b), and mapping fishing grounds (Paul et al., 2016). Several smart phone apps have been developed to date, including (1) Abalobi that provides (non-reef) small-scale fisheries in South Africa with a platform for data collection, supply chain traceability, real-time market information, and direct access to purchasers (UNESCO, 2018), (2) OurFish created by Rare that acts as a fisheries monitoring system and finance management system for reef fisheries in Honduras and Belize ${ }^{1}$, (3) PeskAAS created by WorldFish that acts as a monitoring system for small-scale fisheries in Timor-Leste and could be used as a platform for providing fishers with market information (Tilley et al., 2020), and (4) PescaData created by COBI which allows small-scale fishers in Mexico to monitor effort and catch, obtain real-time market information, and have direct access to the marketplace ${ }^{2}$. The implementation of smartphone apps for reef fishers in additional geographies could support fishery management and monitoring, empower fishers, and increase fisher livelihoods, ultimately leading to more sustainable practices. However, inequity issues may arise from the use of these apps, as significant barriers (e.g., cost of technology, digital literacy, access to electricity and internet) exist to digital inclusion in lowerincome countries.

\footnotetext{
${ }^{1}$ https://rare.org/story/tracing-fish-and-finances/

${ }^{2} \mathrm{https}: / /$ pescadata.org/
} 


\section{Improved Processing and Storage Methods}

Significant value addition occurs for seafood products when appropriate post-harvest handling and processing methods are used, reducing the economic imperative to overfish (Ram et al., 2014). Community training programs have been implemented for Pacific Islands communities for improving the processing of sea cucumber into beche-de-mer for Asian markets, including the distribution of manuals with detailed instructions for improving appearance, smell, and taste to increase market value (Purcell, 2014). Training programs to improve handling and processing techniques could be undertaken for additional exportoriented reef fisheries including sea cucumber fisheries in Latin America and coral reef wildlife collected for the aquarium trade throughout Southeast Asia and Pacific Islands (Wood, 2001; Purcell, 2014). For reef fisheries serving local markets, training in improved post-harvest seafood processing can decrease wastage and increase food security for reef-adjacent communities. For example, improved processing methods could enable households to store fish for times when conditions are not suitable for fishing, create better opportunities to sell seafood to local domestic markets, increase the amount of fish product available for food, improve quality, sanitation and food safety, and increase market access (Bell et al., 2018). Because the lack of cold chain storage capabilities is an additional cause of spoilage of catch from reefs, increased access to cold storage technology could increase catch quality and market value. However, increased access to cold chain storage must be coupled with regulatory or voluntary private sector interventions to ensure fishing effort is not expanded (McClanahan, 1987). Existing promising initiatives include pairing access to cold chain technology with conservation agreements, purchasing contracts with domestic retailers, and sustainable seafood consumer awareness campaigns (Conservation International, 2019).

\section{Formation of Fishing Associations/Cooperatives}

Fishing associations and cooperatives create the conditions for market actors to improve coral reef fisheries sustainability in several ways. First, because small-scale fisheries are typically overlooked by governmental authorities, the amplified voice of formal fisheries organizations can provide fishing communities with improved representation in management processes, legal empowerment to enforce management rules, and increased access to governmental support (Bellchambers et al., 2016; Gardner et al., 2017). Second, cooperatives are better able to engage with several buyers, conferring greater bargaining ability and higher prices. This ability would be particularly beneficial for fishers in the LRFF trade, where the market for this luxury item is highly unpredictable and where fisher exploitation by buyers is particularly rife (Sadovy, 2005). Third, in fisheries where patron-client relationships dominate (where the fisher is dependent on a "patron" for fishing rights, supplies, loans, and/or buying and marketing of catch), the formation of cooperatives could bring together community members with a greater interest in maintaining the health of local marine ecosystems (Berkes et al., 2006). Transitioning from patron-client to cooperative or community-based arrangements can also de-incentivize illegal and unsustainable fishing that may occur when patrons guarantee purchase of catch irrespective of methods (Basurto et al., 2013; Gardner et al., 2017; Nthane et al., 2020). Finally, cooperative governance structures provide an opportunity for vertical integration of the fishery supply chain, including processing, transportation, and commercialization, conferring greater control and profits to fishers (Basurto et al., 2013).

\section{CONCLUSION}

\section{Matching Market Interventions to Coral Reef Fisheries}

Our analysis shows that specific market-based interventions have the potential to increase the sustainability of some reef fisheries. However, these interventions are more likely to be successful when matched to the specific characteristics of the fishery, market, and governance systems. For high value, export-oriented reef fisheries destined for markets with lower engagement in seafood sustainability (i.e., Asia), regulatory approaches in the production geography are the most likely to be effective. This includes import and export restrictions, which hold the greatest promise for regulating markets to reduce highly unsustainable and IUU fisheries such as live reef food fish and beche-de-mer. For high-value, export-oriented species destined for markets with a high level of engagement in sustainability, practitioners should look to certification and ratings efforts, fishery improvement projects, and purchasing commitments from buyers, which hold the greatest promise for fisheries for highly fecund invertebrates such as lobsters (and perhaps mollusks such as octopus). For the aquarium trade, which contains high-value products for export to largely engaged markets but with geographically varied, extremely diffuse and complex supply chains, traceability and transparency efforts may hold greater promise than certification and ratings schemes, which have failed in these fisheries in the past (Supporting Information). For artisanal fisheries targeting species for domestic or regional consumption, sustainable purchasing commitments from retailers, consumer awareness campaigns, and local certification and ratings schemes may help shift attitudes toward sustainability and increasing food security for local communities. Finally, fisher empowerment efforts including access to market information, training on improved post-harvest handling and processing, and formation of fisher associations and cooperatives hold promise for increasing fisher incomes, reducing wasteful catch, increasing food security, and de-incentivizing unsustainable practices.

While certification may only be economically viable for a select group of coral reef fisheries, engagement in the precertification process (i.e., via FIPs) may nevertheless increase the long-term sustainability for "uncertifiable" coral reef fisheries. FIPs utilize market incentives to drive the development of fisheries management plans, harvest control rules, scientific information on stock status, and governmental support in terms of enforcement and development of fishery policies. These improvements are correlated with positive sustainability outcomes for fisheries in general (Cannon et al., 2018; CEA, 
2020a), and could be a powerful catalyst for increasing small-scale coral reef fisheries management capacity in developing countries.

Despite the potential of market-based interventions, specific approaches must be carefully tailored to the ecological and social contexts of these systems. For reef species where certification and FIPs may be viable, several measures must be implemented to promote meaningful improvements to sustainability. These include considerations of ecosystem effects of the fishery, including selecting appropriate spatial scales so that a specific fishery is managed cohesively in a wider ecologically connected seascape (Kittinger et al., 2021). These “jurisdictional approaches" (Kittinger et al., 2021) could be a solution for markets to source from regions where management systems recognize the tight link between the productivity of reef fish stocks and the ecological integrity of the coastal habitats they utilize at various life stages (coral reefs, seagrasses, and mangroves), and accounting for synergistic effects of fishing and other human stressors, including climate change and pollution (Pratchett et al., 2008). Other voluntary private sector commitments such as sustainable sourcing policies and sustainability ratings systems can also play a role in catalyzing consumer and governmental support for improving fishing practices on coral reefs. However, due to the inability of most reef species to supply commercial markets in a sustainable manner, traditional regulatory approaches must be implemented in tandem with private sector initiatives and capacity building approaches to ensure fishing effort is kept within sustainable levels. A robust collaboration between governments, nongovernmental organizations, and fishing communities could ensure that the complex social-ecological system of reef fisheries is considered so that livelihoods are improved without increased damage to reef ecosystems (Blasiak et al., 2017).

\section{Moving Market-Based Interventions Into Reef Conservation}

Market-based interventions have been part of the landscape of fisheries conservation initiatives for over a decade. A myriad of tools and resources have been developed to support these efforts, including (for example) guidance on certifications (e.g., Marine Stewardship Council, 2019), fishery improvement projects (Conservation Alliance for Seafood Solutions, 2021), marketing of sustainable seafood (UC Santa Barbara, 2014) and much more. Some of these mechanisms have highly developed indicators and evaluation processes to determine sustainability (e.g., to meet the criteria for certification), while others are more nascent with respect to how they set standards and evaluate impact. Additionally, the theories of change underpinning these approaches can vary both in terms of the intervention (e.g., consumer education versus export regulations) and the specific geography, production mode (i.e., aquaculture versus wild-capture fisheries) and other factors. The diverse set of market-based strategies also continues to evolve, as practitioners, researchers, and advocates continue to meld, shape, and innovate in the field. Last, a growing literature has begun to evaluate the impacts of these initiatives (CEA, 2014, 2020a,b; Carlson and Palmer, 2016; Cannon et al.,
2018; Travaille et al., 2019; Arton et al., 2020), but it is still a relatively underdeveloped space in terms of science and evidence, which provides ample opportunity for researchers seeking to evaluate these practices and their level of impact on nature and people.

Ultimately, markets will continue to shape coral reef outcomes, driven by increased demand, limited production, and the shifting ways in which communities, reefs, and economies interact. Given the pervasive influence these economic activities continue to have on reefs, our analysis shows there is much that may be gained by exploring market-based solutions to confront the coral reef crisis. This will require practitioners and researchers alike to look beyond the reef itself, and to think creatively about "off the hook" solutions that engage supply chains, market actors, and regulatory solutions that can incentivize sustainable practices in the Anthropocene.

\section{The Inherent Unsustainability of Commercial Coral Reef Fisheries}

With few exceptions, coral reefs cannot sustainably support industrial fishing activities, and especially those that flow into high-volume export markets. For this reason, and to ensure food security for local communities, most reef species (except for a select number of highly fecund invertebrate species such as lobsters and mollusks) should be consumed locally. Sustainability appears to be achievable for reef fisheries under select conditions: traditional management approaches have enabled long-term sustainable use of coral reef resources for local consumption (McClenachan and Kittinger, 2012; Pauly and Zeller, 2014). However, traditional fishing practices have given way to use of highly efficient modern gear, and village consumption of reef resources is giving way to marketoriented fisheries production (McClenachan and Kittinger, 2012). A strong case can be made for shifting commercial fishing away from coral reefs altogether and focusing it instead on tropical pelagics, as these species are harder to overfish and recover more quickly when overfished (Birkeland, 2017). In some Pacific Island nations, governmental policies have encouraged dietary shifts that have driven consumption away from reef fisheries and promoted recovery of fish stocks (Bell et al., 2009). It is therefore imperative that marketbased interventions do not increase fishing effort on reefs, for example by linking additional coral reef fisheries into global markets or creating new markets for fisheries that are already depleted or fully fished (Stratoudakis et al., 2016). Finally, to allow reef fisheries and reef ecosystems to recover, the current transition away from wild capture coral reef fisheries and toward aquaculture and mariculture of highly fecund, low trophic level species (such as lobsters, beche-de-mer, and ornamental species) must continue (Hair et al., 2002; Lovatelli et al., 2004; Bell et al., 2009).

\section{DATA AVAILABILITY STATEMENT}

The raw data supporting the conclusions of this article will be made available by the authors, without undue reservation. 


\section{AUTHOR CONTRIBUTIONS}

$\mathrm{KC}$ and JK conceptualized study. KC synthesized literature and compiled coral reef fisheries statistics from Sea Around Us Project. $\mathrm{KC}$ and $\mathrm{JK}$ wrote first draft of the manuscript and contributed significantly to subsequent iterations of manuscript.

\section{FUNDING}

We gratefully acknowledge funding support from the National Science Foundation (Award No. 1923649).

\section{REFERENCES}

Alfnes, F. (2017). Selling only sustainable seafood: attitudes toward public regulation and retailer policies. Mar. Policy 78, 74-79. doi: 10.1016/j.marpol. 2017.01.012

Arton, A., Leiman, A., Petrokofsky, G., Toonen, H., and Longo, C. S. (2020). What do we know about the impacts of the Marine Stewardship Council seafood ecolabelling program? A systematic map. Environ. Evid. 9, 1-20.

Aswani, S., and Sabetian, A. (2010). Implications of urbanization for artisanal parrotfish fisheries in the Western Solomon Islands. Conserv. Biol. 24, 520-530. doi: 10.1111/j.1523-1739.2009.01377.x

Bailey, M., Bush, S. R., Miller, A., and Kochen, M. (2016). The role of traceability in transforming seafood governance in the global South. Curr. Opin. Environ. Sustain. 18, 25-32. doi: 10.1016/j.cosust.2015.06.004

Bailey, M., Packer, H., Schiller, L., Tlusty, M., and Swartz, W. (2018). The role of corporate social responsibility in creating a Seussian world of seafood sustainability. Fish. Fish. 19, 782-790. doi: 10.1111/faf.12289

Basurto, X., Bennett, A., Weaver, A. H., Dyck, S. R., and Aceves-Bueno, J. S. (2013). Cooperative and noncooperative strategies for small-scale fisheries' selfgovernance in the globalization era: implications for conservation. Ecol. Soc. 18:38.

Bell, J. D., Cisneros-Montemayor, A., Hanich, Q., Johnson, J. E., Lehodey, P., Moore, B. R., et al. (2018). Adaptations to maintain the contributions of smallscale fisheries to food security in the Pacific Islands. Mar. Policy 88, 303-314. doi: 10.1016/j.marpol.2017.05.019

Bell, J. D., Kronen, M., Vunisea, A., Nash, W. J., Keeble, G., Demmke, A., et al. (2009). Planning the use of fish for food security in the Pacific. Mar. Policy 33, 64-76. doi: 10.1016/j.marpol.2008.04.002

Bellchambers, L. M., Gaughan, D. J., Wise, B. S., Jackson, G., and Fletcher, W. J. (2016). Adopting Marine Stewardship Council certification of Western Australian fisheries at a jurisdictional level: the benefits and challenges. Fish. Res. 183, 609-616. doi: 10.1016/j.fishres.2016.07.014

Berkes, F., Hughes, T. P., Steneck, R. S., Wilson, J. A., Bellwood, D. R., Crona, B., et al. (2006). Globalization, roving bandits, and marine resources. Science 311, 1557-1558. doi: 10.1126/science.1122804

Bevilacqua, A. H. V., Angelini, R., Steenbeek, J., Christensen, V., and Carvalho, A. R. (2019). Following the fish: The role of subsistence in a fish-based value chain. Ecol. Econ. 159, 326-334. doi: 10.1016/j.ecolecon.2019.02.004

Biery, L. (2011). The sustainable special: can restaurants encourage sustainable seafood consumption? Sea Around Project News. 63, 1-2. doi: 10.1016/j.spc. 2015.10.004

Birkeland, C. (2017). Working with, not against, coral-reef fisheries. Coral Reefs 36, 1-11. doi: 10.1007/s00338-016-1535-8

Blackmore, E., Norbury, H., Mohammed, E. Y., Bartolini Cavicchi, S., and Wakeford, R. (2015). What's the catch? Lessons from and prospects for the Marine Stewardship Council certification in developing countries. London: IIED.

Blasiak, R., Huang, J. H., Ishihara, H., Kelling, I., Lieng, S., Lindoff, H., et al. (2017). Promoting diversity and inclusiveness in seafood certification and ecolabelling: prospects for Asia. Mar. Policy 85, 42-47. doi: 10.1016/j.marpol.2017.08.011

\section{ACKNOWLEDGMENTS}

We thank to John Claussen, Colette Wabnitz, Elena Finkbeiner, Sara McDonald, Meredith Lopuch, Lydia Teh, Johann Bell, Jennifer Jacquet, Erin Murphy, Miranda Bernard, Gabrielle Lout, and Leah Gerber for sharing their helpful insights.

\section{SUPPLEMENTARY MATERIAL}

The Supplementary Material for this article can be found online at: https://www.frontiersin.org/articles/10.3389/fmars. 2021.675274/full\#supplementary-material

Blue Solutions, (2018). Solutions in Focus: Sustainable Fisheries and Aquaculture. Gland: International Union for Conservation of Nature.

Brewer, T. D. (2011). Coral Reef Fish Value Chains in Solomon Islands: Market Opportunities and Market Effects on Fish Stocks. ARC Centre of Excellence for Coral Reef Studies Report to Solomon Islands Ministry of Fisheries and Marine Resources and Secretariat of the Pacific Community. 46.

Brewer, T. D., Cinner, J. E., Green, A., and Pressey, R. L. (2013). Effects of human population density and proximity to markets on coral reef fishes vulnerable to extinction by fishing. Conserv. Biol. 27, 443-452. doi: 10.1111/j.1523-1739. 2012.01963.x

Burke, L., Reytar, K., Spalding, M., and Perry, A. (2011). Reefs at Risk Revisited. Washington DC: World Resources Institute.

Cannon, J., Sousa, P., Katara, I., Veiga, P., Spear, B., Beveridge, D., et al. (2018). Fishery improvement projects: performance over the past decade. Mar. Policy 97, 179-187. doi: 10.1016/j.marpol.2018.06.007

Cano Chacon, M. (2013). The Role of the Information of the Marine Stewardship Council Certification Process in Developing Countries: A Case Study of Two Mexico MSC Fisheries Certified in Mexico. M.Sc. thesis. Halifax: Dalhousie University.

Carlson, A., and Palmer, C. (2016). A qualitative meta-synthesis of the benefits of eco-labeling in developing countries. Ecol. Econ. 127, 129-145. doi: 10.1016/j. ecolecon.2016.03.020

Castrejón, M., and Charles, A. (2013). Improving fisheries co-management through ecosystem-based spatial management: the Galapagos Marine Reserve. Mar. Policy 38, 235-245. doi: 10.1016/j.marpol.2012. 05.040

Castrejón, M., and Charles, A. (2020). Human and climatic drivers affect spatial fishing patterns in a multiple-use marine protected area: the Galapagos Marine Reserve. PLoS One 15:e0228094. doi: 10.1371/journal.pone.022 8094

CEA, (2014). Business Commitments to Sustainable Seafood: Success Stories and Lessons Learned. San Francisco: California Environmental Associates.

CEA, (2020a). Global Landscape Review of Fishery Improvement Projects. San Francisco: California Environmental Associates.

CEA, (2020b). Progress toward Sustainable Seafood - By the Numbers. San Francisco: California Environmental Associates.

Cinner, J. (2014). Coral reef livelihoods. Curr. Opin. Environ. Sustain. 7, 65-71. doi: 10.1016/j.cosust.2013.11.025

Cinner, J. E., Maire, E., Huchery, C., MacNeil, M. A., Graham, N. A., Mora, C., et al. (2018). Gravity of human impacts mediates coral reef conservation gains. Proc. Natl. Acad. Sci. U.S.A. 115, E6116-E6125.

Clark, C. W., Munro, G. R., and Sumaila, U. R. (2005). Subsidies, buybacks, and sustainable fisheries. J. Environ. Econ. Manag. 50, 47-58. doi: 10.1016/j.jeem. 2004.11.002

Conand, C. (2006). "Sea cucumber biology, taxonomy, distribution and conservation status," in Proceedings of the CITES Workshop on the Conservation of Sea Cucumbers in the Families Holothuriidae and Stichopodidae, ed. A. W. Bruckner (Silver Spring: NOAA Technical Memorandum), 1-17. doi: 10.23880/ izab- 16000185 
Conservation Alliance for Seafood Solutions (CASS), (2021). Guidelines for Supporting Fishery Improvement Projects. Available online at: http://solutionsforseafood.org/wp-content/uploads/2021/02/FIP-GuidelinesJanuary-2021.pdf (accessed June 22, 2021).

Conservation International, (2019). EcoGourmet: Sustainable and Equitable Business Model in the Value Chain of Artisanal Fisheries. Arlington County, VI: Conservation International.

Certification and Ratings Collaboration (CRC), (2020). Sustainable Seafood: A Global Benchmark. Available online at: https://certificationandratings.org/ sustainable-seafood-a-global-benchmark/ (accessed June 22, 2021).

Crona, B., and Bodin, O. (2010). Power asymmetries in small-scale fisheries: a barrier to governance transformability? Ecol. Soc. 15:32.

Dalzell, P., Adams, T. J. H., and Polunin, N. V. C. (1996). Coastal fisheries in the Pacific Islands. Oceanogr. Mar. Biol. Annu. Rev. 34, 395-531.

Dee, L. E., Horii, S. S., and Thornhill, D. J. (2014). Conservation and management of ornamental coral reef wildlife: successes, shortcomings, and future directions. Biol. Conserv. 169, 225-237. doi: 10.1016/j.biocon.2013.11.025

Environmental Justice Foundation, (2014). Combating Pirate Fishing with the Power of Technology. Available online at: https://ejfoundation.org/news-media/ combating-pirate-fishing-with-the-power-of-technology (accessed June 22, 2021).

Ferse, S. C., Glaser, M., Neil, M., and Mánez, K. S. (2014). To cope or to sustain? Eroding long-term sustainability in an Indonesian coral reef fishery. Reg. Environ. Chang. 14, 2053-2065. doi: 10.1007/s10113-012-0342-1

Fishery Progress, (2020). FIP Directory. Available online at: https://fisheryprogress. org/directory (accessed June 22, 2021).

Friedlander, A. M. (2015). "A perspective on the management of coral reef fisheries," in Ecology of Fishes on Coral Reefs, ed. C. Mora (Cambridge: Cambridge University Press), 208-214. doi: 10.1017/cbo9781316105 412.023

Friedman, K., Eriksson, H., Tardy, E., and Pakoa, K. (2011). Management of sea cucumber stocks: patterns of vulnerability and recovery of sea cucumber stocks impacted by fishing. Fish Fish. 12, 75-93. doi: 10.1111/j.1467-2979.2010.00 384.x

Frost, E. (2017). There's an App for That: Using Phones to Help Make Fishing Sustainable. Available online at: https://ocean.si.edu/ocean-life/fish/theresapp-using-phones-help-make-fishing-sustainable (accessed June 22, 2021).

Gardner, C. J., Rocliffe, S., Gough, C., Levrel, A., Singleton, R. L., Vincke, X., et al. (2017). "Value chain challenges in two community-managed fisheries in western Madagascar: insights for the small-scale fisheries guidelines," in The SmallScale Fisheries Guidelines. MARE Publication Series, Vol. 14, eds S. Jentoft, R. Chuenpagdee, M. Barragán-Paladines, and N. Franz (Cham: Springer).

Grafeld, S., Oleson, K. L. L., Teneva, L., and Kittinger, J. N. (2017). Follow that fish: uncovering the hidden blue economy in coral reef fisheries. PLoS One 12:e0182104. doi: 10.1371/journal.pone.0182104

Green, S. J., Akins, J. L., Maljković, A., and Côté, I. M. (2012). Invasive lionfish drive Atlantic coral reef fish declines. PLoS One 7:e32596. doi: 10.1371/journal. pone.0032596

Gulbrandsen, L. (2009). The emergence and effectiveness of the Marine Stewardship Council. Mar. Policy 33, 654-660. doi: 10.1016/j.marpol.2009. 01.002

Gutierrez, N. L., Defeo, O., Bush, S. R., Butterworth, D. S., Roheim, C. A., and Punt, A. E. (2016). The current situation and prospects of fisheries certification and ecolabelling. Fish Res. 182, 1-6. doi: 10.1016/j.fishres.2016.05.004

Guzman, H. M., and Guevara, C. A. (2002). Population structure, distribution, and abundance of three commercial species of sea cucumber (Echinodermata) in Panama. Caribb. J. Sci. 38, 230-238.

Hair, C. A., Bell, J. D., and Doherty, P. J. (2002). "The use of wild-caught juveniles in coastal aquaculture and its application to coral reef fishes," in Responsible Marine Aquaculture, eds R. R. Stickney, and J. P. McVey (Wallingford: CAB International), 327-353. doi: 10.1079/9780851996042.0327

Hori, J., Wakamatsu, H., Miyata, T., and Oozeki, Y. (2020). Has the consumers awareness of sustainable seafood been growing in Japan? Implications for promoting sustainable consumerism at the Tokyo 2020 Olympics and Paralympics. Mar. Policy 115:103851. doi: 10.1016/j.marpol.2020.103851

Hughes, T., Baird, A., Bellwood, D., Card, M., Connolly, S., Folke, C., et al. (2003). Climate change, human impacts, and the resilience of coral reefs. Science 301, 929-933. doi: $10.1126 /$ science. 1085046
Jackson, J. B. C., Donovan, M. K., Cramer, K. L., and Lam, V. V. (2014). Status and Trends of Caribbean Coral Reefs 1970-2012. Gland: Global Coral Reef Monitoring Network, IUCN.

Jacquet, J., Hocevar, J., Lai, S., Majluf, P., Pelletier, N., Pitcher, T., et al. (2009). Conserving wild fish in a sea of market-based efforts. Oryx 44, 45-56. doi: $10.1017 / \mathrm{s} 0030605309990470$

Jameson, S. C., McManus, J. W., and Spalding, M. D. (1995). State of the Reefs: Regional and Global Perspectives, ed. S. C. Jameson (Bethesda: National Oceanic and Atmospheric Administration).

Jeffers, V. F., Humber, F., Nohasiarivelo, T., Botosoamananto, R., and Anderson, L. G. (2019). Trialling the use of smartphones as a tool to address gaps in smallscale fisheries catch data in southwest Madagascar. Mar. Policy 99, 267-274. doi: 10.1016/j.marpol.2018.10.040

Kittinger, J. N., Bernard, M., Finkbeiner, E., Murphy, E., Obregon, P., Klinger, D. H., et al. (2021). Applying a jurisdictional approach to support sustainable seafood. Conserv. Sci. Pract. 3:e386.

Kronen, M., Sauni, S., Magron, F., and Fay-Sauni, L. (2006). "Status of reef and lagoon resources in the South Pacific - the influence of socioeconomic factors," in Proceedings of the 10th International Coral Reef Symposium (Noumea: Secretariat of the Pacific Community), 1185-1193.

Lawley, M., Craig, J. F., Dean, D., and Birch, D. (2019). The role of seafood sustainability knowledge in seafood purchase decisions. Br. Food J. 121, 23372350. doi: 10.1108/bfj-08-2018-0513

Lee, M. K. K. (2020). The Responsible Seafood Tool (RESET): empowering businesses in Asia to source seafood more responsibly. IOP Conf. Ser. Earth Environ. Sci. 414:012009. doi: 10.1088/1755-1315/414/1/012009

Leenhardt, P., Lauer, M., Madi Moussa, R., Holbrook, S. J., Rassweiler, A., Schmitt, R. J., et al. (2016). Complexities and uncertainties in transitioning small-scale coral reef fisheries. Front. Mar. Sci. 3:70. doi: 10.3389/fmars.2016. 00070

Lin, P. (2020). Sustainable Eco-Labelled Seafood from the East China Sea: Regional and General Regulatory Regimes. J.D. thesis. University Park, PA: Penn State Law School.

Lopuch, M. (2008). "Benefits of certification for small-scale fisheries," in Seafood Ecolabelling, Principles and Practice, eds T. J. Ward, and B. F. Phillips (Chichester: Wiley-Blackwell), 307-321. doi: 10.1002/9781444301380.ch15

Lovatelli, A., Conand, C., Purcell, S., Uthicke, S., Hamel, S. F., and Mercier, A. (2004). Advances in Sea Cucumber Aquaculture and Management (No. 463). Food and Agriculture Organization Fisheries Technical Paper 463. Rome: FAO, 425.

MacNeil, M. A., Graham, N. A., Cinner, J. E., Wilson, S. K., Williams, I. D., Maina, J., et al. (2015). Recovery potential of the world's coral reef fishes. Nature 520, 341-344.

Marine Stewardship Council (MSC), (2009). Net Benefits: the First Ten Years of MSC-Certified Sustainable Fisheries. London: MSC.

Marine Stewardship Council (MSC), (2019). MSC General Certification Requirements. Available online at: https://www.msc.org/docs/defaultsource/default-document-library/for-business/program-documents/generalcertification-requirements/msc-general-certification-requirements-v2-4.pdf? sfvrsn=d1b5f2f_20 (accessed June 22, 2021).

Marine Stewardship Council (MSC), (2020). Our Approach. Available online at: https://www.msc.org/what-we-are-doing/our-approach (accessed June 22, 2021).

McClanahan, T. R. (1987). Overfishing and coral reef degradation: a preliminary report from East Africa. Conserv. Biol. 1, 97-99. doi: 10.1111/j.1523-1739.1987. tb00019.x

McClanahan, T. R., and Cinner, J. E. (2008). A framework for adaptive gear and ecosystem-based management in the artisanal coral reef fishery of Papua New Guinea. Aquat. Conserv. 18, 493-507. doi: 10.1002/aqc. 874

McClenachan, L., and Kittinger, J. N. (2012). Multicentury trends and the sustainability of coral reef fisheries in Hawai'i and Florida. Fish Fish. 14, 239-255. doi: 10.1111/j.1467-2979.2012.00465.x

Moberg, F., and Folke, C. (1999). Ecological goods and services of coral reef ecosystems. Ecol. Econ. 29, 215-233. doi: 10.1016/s0921-8009(99)00009-9

Newton, K., Côté, I. M., Pilling, G. M., Jennings, S., and Dulvy, N. K. (2007). Current and future sustainability of island coral reef fisheries. Curr. Biol. 17, 655-658. doi: 10.1016/j.cub.2007.02.054 
Nisanala, A., Kodikara, D. K., Keppitiyagama, C., and Nirmal, I. (2015). ICT solution to minimize illegal, unreported and unregulated (IUU) fishing. Int. J. Res. Granthaalayah. 3, 117-127. doi: 10.29121/granthaalayah.v3.i10.2015.2937

Nthane, T. T., Saunders, F., Gallardo Fernández, G. L., and Raemaekers, S. (2020). Toward sustainability of South African small-scale fisheries leveraging ICT transformation pathways. Sustainability 12:743. doi: 10.3390/su1202 0743

Pandolfi, J. M., Bradbury, R. H., Sala, E., Hughes, T. P., Bjorndal, K. A., Cooke, R. G., et al. (2003). Global trajectories of the long-term decline of coral reef ecosystems. Science 301, 955-958. doi: 10.1126/science.1085706

Paul, S. A. L., Wilson, A. M. W., Cachimo, R., and Riddell, M. A. (2016). Piloting participatory smartphone mapping of intertidal fishing grounds and resources in northern Mozambique: opportunities and future directions. Ocean Coast Manag. 134, 79-92. doi: 10.1016/j.ocecoaman.2016.09.018

Pauly, D., and Chua, T. E. (1988). The overfishing of marine resources: socioeconomic background in Southeast Asia. Ambio 17, 200-206.

Pauly, D., and Zeller, D. (eds) (2015). Catch Reconstruction: Concepts, Methods and Data Sources. Vancouver, BC: University of British Columbia.

Pauly, D., and Zeller, D. (2014). Accurate catches and the sustainability of coral reef fisheries. Curr. Opin. Environ. Sustain. 7, 44-51. doi: 10.1016/j.cosust.2013. 11.027

Pérez-Ramírez, M., Castrejón, M., Gutiérrez, N. L., and Defeo, O. (2016). The Marine Stewardship Council certification in Latin America and the Caribbean: a review of experiences, potentials and pitfalls. Fish Res. 182, 50-58. doi: 10.1016/j.fishres.2015.11.007

Phillips, B., Ward, T., and Chaffee, C. (2003). "The western rock lobster: The fishery and its assessment," in Eco-Labelling in Fisheries What is it All About?, eds B. Phillips, T. Ward, and C. Chaffee (Oxford: Blackwell Science), 94-102.

Ponte, S. (2008). "The marine stewardship council and developing countries. Seafood ecolabelling, principles and practice," in Seafood Ecolabelling: Principles and Practice, eds T. Ward, and B. Phillips (Oxford: Wiley \& Sons), 287-306. doi: $10.1002 / 9781444301380 . c h 14$

Pratchett, M. S., Munday, P., Wilson, S. K., Graham, N. A., Cinner, J. E., Bellwood, D. R., et al. (2008). Effects of climate-induced coral bleaching on coral-reef fishes. Ecological and economic consequences. Oceanogr. Mar. Biol. Annu. Rev. 46, 251-296. doi: 10.1201/9781420065756.ch6

Purcell, S. W. (2014). Processing Sea Cucumbers into Beche-de-mer: a Manual for Pacific Island Fishers. SPC/SCU. Available online at: https://aciar.gov.au/publication/books-and-manuals/processing-seacucumbers-beche-de-mer-manual-pacific-island-fishers (accessed June 22, 2021).

Purcell, S. W., Mercier, A., Conand, C., Hamel, J. F., Toral-Granda, M. V., Lovatelli, A., et al. (2013). Sea cucumber fisheries: global analysis of stocks, management measures and drivers of overfishing. Fish Fish. 14, 34-59. doi: 10.1111/j.14672979.2011.00443.x

Purcell, S. W., Ngaluafe, P., Foale, S. J., Cocks, N., Cullis, B. R., and Lalavanua, W. (2016). Multiple factors affect socioeconomics and wellbeing of artisanal sea cucumber fishers. PLoS One 11:e0165633. doi: 10.1371/journal.pone.0165633

Ram, R., Chand, R. V., and Southgate, P. C. (2014). Effects of processing methods on the value of bêche-de-mer from the Fiji Islands. J. Mar. Sci. Res. Dev. 4, 1-7.

Republic of Palau, (2019). Path to 3030: First Voluntary National Review of the SDGs. Available online at: https://sustainabledevelopment.un.org/content/ documents/23606VNR_FINAL_21June2019_UN_Version.pdf (accessed June 22, 2021).

Rhyne, A. L., Tlusty, M. F., and Kaufman, L. (2014). Is sustainable exploitation of coral reefs possible? A view from the standpoint of the marine aquarium trade. Curr. Opin. Environ. Sustain. 7, 101-107. doi: 10.1016/j.cosust.2013. 12.001

Roheim, C. A., Bush, S. R., Asche, F., Sanchirico, J. N., and Uchida, H. (2018). Evolution and future of the sustainable seafood market. Nat. Sustain. 1, 392398. doi: 10.1038/s41893-018-0115-Z

Ross Strategic, Global Impact Advisors, and EON Impact Consulting, (2020). Global Seafood Markets Strategy Evaluation Final Report. Our Shared Seas. Available online at: https://www.packard.org/wp-content/uploads/2020/10/ Global-Seafood-Markets-Strategy-Evaluation-Final-Report.pdf (accessed June 22, 2021).

Sadovy, Y. (2005). Trouble on the reef: the imperative for managing vulnerable and valuable fisheries. Fish Fish. 6, 167-185. doi: 10.1111/j.1467-2979.2005.00186.x
Sadovy, Y., Donaldson, T., Graham, T., McGilvray, F., Muldoon, G., Phillips, M. J., et al. (2003). While Stocks Last: the Live Reef Food Fish Trade. Manila: Asian Development Bank.

Sadovy, Y. J., and Vincent, A. C. J. (2002). "Ecological issues and the trades in live reef fishes," in Coral Reef Fishes: Dynamics and Diversity in a Complex Ecosystem, ed. P. F. Sale (San Diego: Academic Press), 391-420. doi: 10.1016/ b978-012615185-5/50023-2

Sadovy de Mitcheson, Y. S., and Yin, X. (2015). "Cashing in on coral reefs: the implications of exporting reef fishes," in Ecology of Fishes on Coral Reefs, ed. C. Mora (Cambridge: Cambridge University Press), 166-181. doi: 10.1017/ cbo9781316105412.019

Sale, P. (2008). Management of coral reefs: where we have gone wrong and what we can do about it. Mar. Pollut. Bull. 56, 805-809. doi: 10.1016/j.marpolbul.2008. 04.009

Sampson, G. S., Sanchirico, J. N., Roheim, C. A., Bush, S. R., Taylor, J. E., Allison, E. H., et al. (2015). Secure sustainable seafood from developing countries. Science 348, 504-506. doi: 10.1126/science.aaa4639

Schuhbauer, A., and Sumaila, U. R. (2016). Economic viability and small-scale fisheries - a review. Ecol. Econ. 124, 69-75. doi: 10.1016/j.ecolecon.2016. 01.018

Seafood Watch, (2020). Business Collaboration. Available online at: https:// www.seafoodwatch.org/businesses-and-organizations/business-collaborations (accessed June 22, 2021).

Simons, L. (2017). Changing the Food Game: Market Transformation Strategies for Sustainable Agriculture. Milton Park: Routledge.

Smith, N. S., and Zeller, D. (2016). Unreported catch and tourist demand on local fisheries of small island states: the case of The Bahamas, 1950-2010. Fish Bull. 114, 117-131. doi: 10.7755/fb. 114.1.10

Stratoudakis, Y., McConney, P., Duncan, J., Ghofar, A., Gitonga, N., Mohamed, K. S., et al. (2016). Fisheries certification in the developing world: locks and keys or square pegs in round holes? Fish Res. 182, 39-49. doi: 10.1016/j.fishres. 2015.08.021

Sutton, M. (1998). "Harnessing market forces and consumer power in favour of sustainable fisheries," in Reinventing Fisheries Management, eds T. J. Pitcher, P. Hart, and D. Pauly (Dordrecht: Springer), 125-135. doi: 10.1007/978-94-0114433-9_8

Teh, L. S., Teh, L. C., and Sumaila, U. R. (2013). A global estimate of the number of coral reef fishers. PLoS One 8:e65397. doi: 10.1371/journal.pone.0065397

Tilley, A., Dos Reis Lopes, J., and Wilkinson, S. P. (2020). PeskAAS: a near-realtime, open-source monitoring and analytics system for small-scale fisheries. PLoS One 15:e0234760. doi: 10.1371/journal.pone. 0234760

Tindall, C. (2009). "Fisheries supply chain issues for developing countries," in From Hook to Plate: the State of Marine fisheries. A Commonwealth Perspective, eds R. Bourne, and M. Collins (London: Commonwealth Foundation), 129-146.

Travaille, K. L., Lindley, J., Kendrick, G. A., Crowder, L. B., and Clifton, J. (2019). The market for sustainable seafood drives transformative change in fishery social-ecological systems. Glob. Environ. Chang. 57:101919. doi: 10.1016/j. gloenvcha.2019.05.003

UC Santa Barbara, (2014). Market Your Catch. Available online at: https:// marketyourcatch.msi.ucsb.edu/ (accessed June 22, 2021).

UNESCO, (2018). ABALOBI: A Case Study. UNESCO-Pearson Initiative for Literacy: Improved Livelihoods in a Digital World. Paris: UNESCO.

Uthicke, S., Welch, D., and Benzie, J. A. H. (2004). Slow growth and lack of recovery in overfished holothurians on the Great Barrier Reef: evidence from DNA fingerprints and repeated large-scale surveys. Conserv. Biol. 18, 1395-1404. doi: 10.1111/j.1523-1739.2004.00309.x

Wabnitz, C., Taylor, M., Green, A., and Razak, T. (2003). From Ocean to Aquarium the Global Trade in Marine Ornamental Species. Cambridge: UNEP-WCMC.

Wabnitz, C. C. (2019). "Adapting tourist seafood consumption practices in Pacific Islands to climate change," in Predicting Future Oceans, eds A. M. CisnerosMontemayor, W. W. L. Cheung, and Y. Ota (Amsterdam: Elsevier), 215-225. doi: 10.1016/b978-0-12-817945-1.00020-4

Wakamatsu, M., and Wakamatsu, H. (2017). The certification of small-scale fisheries. Mar. Policy 77, 97-103. doi: 10.1016/j.marpol.2016.12.016

Washington, S., and Ababouch, L. (2011). Private Standards and Certification in Fisheries and Aquaculture. Rome: Food and Agriculture Organization of the United Nations. 
Wood, E. (2001). Collection of Coral Reef Fish for Aquaria: Global Trade, Conservation Issues and Management Strategies. Ross-on-Wye: Marine Conservation Society, 80.

Xu, P., Zeng, Y., Fong, Q., Lone, T., and Liu, Y. (2012). Chinese consumers' willingness to pay for green-and eco-labeled seafood. Food Control 28, 74-82. doi: $10.1016 /$ j.foodcont.2012.04.008

Zou, C. (2017). A Study of Chinese Consumer Preferences for Sustainably Farmed Seafood. Ph.D. thesis. Kingston, RI: University of Rhode Island.

Conflict of Interest: The authors declare that the research was conducted in the absence of any commercial or financial relationships that could be construed as a potential conflict of interest.
Publisher's Note: All claims expressed in this article are solely those of the authors and do not necessarily represent those of their affiliated organizations, or those of the publisher, the editors and the reviewers. Any product that may be evaluated in this article, or claim that may be made by its manufacturer, is not guaranteed or endorsed by the publisher.

Copyright (c) 2021 Cramer and Kittinger. This is an open-access article distributed under the terms of the Creative Commons Attribution License (CC BY). The use, distribution or reproduction in other forums is permitted, provided the original author(s) and the copyright owner(s) are credited and that the original publication in this journal is cited, in accordance with accepted academic practice. No use, distribution or reproduction is permitted which does not comply with these terms. 